\title{
24. VELOCITY ANISOTROPY AND PHYSICAL PROPERTIES OF DEEP-SEA SEDIMENTS FROM THE WESTERN SOUTH ATLANTIC
}

\author{
R.L. Carlson and N.I. Christensen, Department of Geological Sciences, \\ University of Washington, Seattle, Washington
}

\section{INTRODUCTION}

Compressional and shear wave velocities have been measured at confining pressures up to $6.0 \mathrm{kbar}$ for a dolostone and a sedimentary breccia from Site 357. Selected elastic properties computed from the velocities and densities are also reported. The dolostone is composed largely of silt-sized dolomite rhombs with significant amounts of micrite and silica cement. The dark greenish-gray breccia is composed of glassy basalt fragments and a few sediment clasts, with a mean grain size of $2-4 \mathrm{~mm}$. The angular to subangular basalt fragments contain many calcite-filled vesicles and abundant microcrystalline plagioclase and pyroxene. A few larger pyroxene crystals are also present in the basalt and in the matrix, which appears to be composed of silica, clay, and calcite.

In addition, compressional wave velocities were measured at confining pressures up to $1.0 \mathrm{kbar}$ in samples cut parallel and perpendicular to the drill core axes of 11 zero sections. Porosities and wet bulk densities were also determined. These samples are highly calcareous, ranging from chalk to limestone, and all display significant velocity anisotropy with the high velocities in the horizontal direction.

\section{PROCEDURE}

Water saturation and porosity have been recognized as significant variables affecting the elastic properties of rocks (e.g., Wyllie et al., 1958; Nur and Simmons, 1969). For sediments, water saturation is a particularly important parameter (Hamilton, 1971). Thus to ensure maximum water saturation, all samples discussed in this paper were shipped to the shore laboratory in sealed, water-filled containers, and saturation was carefully maintained until all measurements were completed.

Two samples in the form of right circular cylinders, $2.54 \mathrm{~cm}$ in diameter and 2.9 to $3.8 \mathrm{~cm}$ in length, were cut from adjacent parts of each of 13 zero sections. The cylinders were cut with axes parallel and perpendicular to the drill core axis so sonic velocities could be measured in vertical and horizontal directions with respect to the sediment column.

Because the water-saturated zero section samples proved to be easily damaged in handling, density and porosity measurements were made using wafers 0.5 to $1.0 \mathrm{~cm}$ thick, trimmed from the ends of the horizontally cut cylinders. After wet bulk densities were determined by immersion, the samples were weighed to the nearest
$0.01 \mathrm{~g}$. Sample volumes were then estimated from the densities and wet weights. Finally, the samples were air dried and weighed again in order to determine the water content, from which porosities were calculated. To check the porosities, sample volumes were also computed from the wafer dimensions. In general, the porosity estimates are accurate to $\pm 4 \%$, provided the samples were completely water saturated. The wet bulk densities of Samples 357-25-2, 20-23 cm and 357-24, CC were calculated from the weights and dimensions of cylinders cut normal to the drill core axis.

Compressional and shear wave velocities were measured by the pulse transmission method as described by Birch (1960). The accuracies of the measurements are estimated to be $0.5 \%$ for compressional and $1.0 \%$ for shear waves at pressures of a few kilobars (Christensen and Shaw, 1970). However, at pressures less than $1.0 \mathrm{kbar}$, the accuracy is probably on the order of $2 \%$. The samples were wrapped in two layers of 100 mesh copper screen, jacketed with copper foil, and enclosed in rubber tubing to prevent the pressure medium from penetrating the rocks during pressure runs. The purpose of the screen is to ensure that pore pressures are maintained at values much lower than the confining pressure. Samples $357-24, \mathrm{CC}$ and $357-25-2,20-23 \mathrm{~cm}$ were tested at pressures up to $6.0 \mathrm{kbar}$, while zero section sample measurements were limited to $1.0 \mathrm{kbar}$.

\section{VELOCITY, DENSITY, AND POROSITY RELATIONS}

Table 1 includes the compressional wave velocities, porosities, densities, anisotropies, and descriptions for the zero section samples. Densities, compressional and shear velocities, and computed elastic constants for the dolostone (347-24, CC) and breccia (357-25-2, 20-23 $\mathrm{cm}$ ) are summarized in Table 2 . Listed elastic properties are: the ratio of compressional to shear wave velocity $\left(V_{p} / V s\right)$, Poisson's ratio $(\sigma)$, bulk modulus $(K)$, shear modulus $(\mu)$, Young's modulus $(E)$, and Lamé's constant $(\lambda)$. The equations relating these parameters to density and velocity are summarized by Birch (1961).

A plot of wet bulk density $\left(\rho_{b}\right)$ versus porosity $(\phi)$ for marine sediments of varied lithology by Hamilton (1970) shows a strong linear trend with a mean grain density $\left(\rho_{g}\right)$ near $2.0 \mathrm{~g} / \mathrm{cc}$. Neglecting the salinity of sea water, the equation relating $\rho_{b}$ and $\phi$ for the sediments under discussion should be approximately

$$
\rho=2.7-1.7 \phi
$$


TABLE 1

Compressional (P) and Shear (S) Wave Velocities

\begin{tabular}{|c|c|c|c|c|c|c|c|c|c|c|c|}
\hline \multirow[b]{2}{*}{ Sample } & \multirow{2}{*}{$\begin{array}{l}\text { Propagation } \\
\text { Direction }\end{array}$} & \multirow{2}{*}{$\begin{array}{c}\text { Bulk } \\
\text { Density } \\
(\mathrm{g} / \mathrm{cc})\end{array}$} & \multirow{2}{*}{$\begin{array}{l}\text { Porosity } \\
(\%)\end{array}$} & \multirow{2}{*}{$\begin{array}{l}\text { Anisotropy } \\
(\% \text { at } 0.1 \mathrm{~kb})\end{array}$} & \multicolumn{6}{|c|}{ Velocity $(\mathrm{km} / \mathrm{sec})$ at Pressure $(\mathrm{kb})$} & \multirow[b]{2}{*}{ Lithology } \\
\hline & & & & & 0.1 & 0.2 & 0.4 & 0.6 & 0.8 & 1.0 & \\
\hline $354-12-0$ & $\begin{array}{l}\mathrm{h} \\
\mathrm{v}\end{array}$ & 1.92 & 42 & 6.9 & $\begin{array}{l}2.11 \\
1.97\end{array}$ & $\begin{array}{l}2.15 \\
2.00\end{array}$ & $\begin{array}{l}2.20 \\
2.06\end{array}$ & $\begin{array}{l}2.25 \\
2.12\end{array}$ & $\begin{array}{l}2.30 \\
2.17\end{array}$ & $\begin{array}{l}2.35 \\
2.21\end{array}$ & $\begin{array}{l}\text { Zeolitic marly } \\
\text { Diatomaceous nanno chalk }\end{array}$ \\
\hline $354-14-0$ & $\begin{array}{l}\mathrm{h} \\
\mathrm{v}\end{array}$ & 2.02 & 35 & 8.0 & $\begin{array}{l}2.61 \\
2.41\end{array}$ & $\begin{array}{l}2.64 \\
2.43\end{array}$ & $\begin{array}{l}2.68 \\
2.44\end{array}$ & $\begin{array}{l}2.73 \\
2.50\end{array}$ & $\begin{array}{l}2.79 \\
2.56\end{array}$ & $\begin{array}{l}2.85 \\
2.62\end{array}$ & Marly nanno chalk \\
\hline $356-27-9$ & $\begin{array}{l}\mathrm{h} \\
\mathrm{v}\end{array}$ & 1.83 & 48 & 8.7 & $\begin{array}{l}1.80 \\
1.65\end{array}$ & $\begin{array}{l}1.83 \\
1.68\end{array}$ & $\begin{array}{l}1.87 \\
1.72\end{array}$ & $\begin{array}{l}1.91 \\
1.77\end{array}$ & $\begin{array}{l}1.95 \\
1.81\end{array}$ & $\begin{array}{l}1.99 \\
1.85\end{array}$ & Foram nanno chalk \\
\hline $356-30-0$ & $\begin{array}{l}\mathrm{h} \\
\mathrm{v}\end{array}$ & 1.96 & 41 & 5.3 & $\begin{array}{l}1.92 \\
1.82\end{array}$ & $\begin{array}{l}1.96 \\
1.85\end{array}$ & $\begin{array}{l}2.02 \\
1.90\end{array}$ & $\begin{array}{l}2.07 \\
1.94\end{array}$ & $\begin{array}{l}2.12 \\
2.00\end{array}$ & $\begin{array}{l}2.14 \\
2.04\end{array}$ & Foram nanno chalk \\
\hline $356-34-9$ & $\mathrm{~h}$ & 2.12 & 33 & & 2.29 & 2.33 & 2.38 & 2.44 & 2.49 & 2.52 & Marly calcareous chalk \\
\hline $356-35-9$ & $\begin{array}{l}\mathrm{h} \\
\mathrm{v}\end{array}$ & 2.18 & 28 & 9.3 & $\begin{array}{l}2.47 \\
2.19\end{array}$ & $\begin{array}{l}2.53 \\
2.22\end{array}$ & $\begin{array}{l}2.62 \\
2.28\end{array}$ & $\begin{array}{l}2.66 \\
2.34\end{array}$ & $\begin{array}{l}2.68 \\
2.40\end{array}$ & $\begin{array}{l}2.68 \\
2.45\end{array}$ & $\begin{array}{l}\text { Dolomitic marly calcareous } \\
\text { chalk }\end{array}$ \\
\hline $356-40-0$ & $\begin{array}{l}\mathrm{h} \\
\mathrm{v}\end{array}$ & 2.19 & 29 & 10.4 & $\begin{array}{l}2.43 \\
2.19\end{array}$ & $\begin{array}{l}2.47 \\
2.22\end{array}$ & $\begin{array}{l}2.54 \\
2.28\end{array}$ & $\begin{array}{l}2.59 \\
2.34\end{array}$ & $\begin{array}{l}2.65 \\
2.40\end{array}$ & $\begin{array}{l}2.70 \\
2.45\end{array}$ & Calcareous mudstone \\
\hline $356-43-0$ & $\begin{array}{l}\mathrm{h} \\
\mathrm{v}\end{array}$ & 2.30 & 24 & 16.2 & $\begin{array}{l}2.99 \\
2.54\end{array}$ & $\begin{array}{l}3.05 \\
2.59\end{array}$ & $\begin{array}{l}3.14 \\
2.68\end{array}$ & $\begin{array}{l}3.21 \\
2.73\end{array}$ & $\begin{array}{l}3.28 \\
2.79\end{array}$ & $\begin{array}{l}3.35 \\
2.84\end{array}$ & Marly limestone \\
\hline $357-26-0$ & $\begin{array}{l}\mathrm{h} \\
\mathrm{v}\end{array}$ & 2.00 & 41 & 5.2 & $\begin{array}{l}1.96 \\
1.86\end{array}$ & $\begin{array}{l}1.99 \\
1.90\end{array}$ & $\begin{array}{l}2.04 \\
1.96\end{array}$ & $\begin{array}{l}2.10 \\
2.01\end{array}$ & $\begin{array}{l}2.14 \\
2.05\end{array}$ & $\begin{array}{l}2.17 \\
2.09\end{array}$ & Limestone \\
\hline $357-28-0$ & $\mathrm{~h}$ & 2.07 & 34 & & 1.58 & 1.80 & 2.05 & 2.10 & 2.14 & 2.19 & Parly silicified limestone \\
\hline $357-34-0$ & $\begin{array}{l}\mathrm{h} \\
\mathrm{v}\end{array}$ & 2.04 & 40 & 7.0 & $\begin{array}{l}2.06 \\
1.92\end{array}$ & $\begin{array}{l}2.09 \\
1.95\end{array}$ & $\begin{array}{l}2.15 \\
2.01\end{array}$ & $\begin{array}{l}2.21 \\
2.07\end{array}$ & $\begin{array}{l}2.28 \\
2.12\end{array}$ & $\begin{array}{l}2.33 \\
2.16\end{array}$ & Foram nanno chalk \\
\hline $357-43-0$ & $\begin{array}{l}\mathrm{h} \\
\mathrm{v}\end{array}$ & 2.13 & 31 & 14.4 & $\begin{array}{l}2.46 \\
2.13\end{array}$ & $\begin{array}{l}2.51 \\
2.16\end{array}$ & $\begin{array}{l}2.57 \\
2.21\end{array}$ & $\begin{array}{l}2.62 \\
2.26\end{array}$ & $\begin{array}{l}2.66 \\
2.31\end{array}$ & $\begin{array}{l}2.71 \\
2.36\end{array}$ & $\begin{array}{l}\text { Marly foram } \\
\text { Nanno limestone }\end{array}$ \\
\hline $357-47-0$ & $\begin{array}{l}\mathrm{h} \\
\mathrm{v}\end{array}$ & 2.30 & 23 & 12.8 & $\begin{array}{l}2.82 \\
2.48\end{array}$ & $\begin{array}{l}2.84 \\
2.53\end{array}$ & $\begin{array}{l}2.85 \\
2.59\end{array}$ & $\begin{array}{l}2.96 \\
2.65\end{array}$ & $\begin{array}{l}2.98 \\
2.72\end{array}$ & $\begin{array}{l}3.00 \\
2.78\end{array}$ & Marly chalk \\
\hline
\end{tabular}

TABLE 2

Elastic Constants

\begin{tabular}{lcccccccc}
\hline $\begin{array}{c}P \\
(\mathrm{~kb})\end{array}$ & $\begin{array}{c}V_{p} \\
(\mathrm{~km} / \mathrm{sec})\end{array}$ & $\begin{array}{c}V_{s} \\
(\mathrm{~km} / \mathrm{sec})\end{array}$ & $V_{p} / V_{s}$ & $\sigma$ & $\begin{array}{c}K \\
(\mathrm{mb})\end{array}$ & $\begin{array}{c}\mu \\
(\mathrm{mb})\end{array}$ & $\begin{array}{c}E \\
(\mathrm{mb})\end{array}$ & $\begin{array}{c}\lambda \\
(\mathrm{mb})\end{array}$ \\
\hline \multicolumn{7}{l}{ Sample } & $357-25-2$, & $20-23 \mathrm{~cm}(\rho=1.964 \mathrm{~g} / \mathrm{cc})^{\mathrm{a}}$ \\
0.2 & 3.50 & 1.60 & 2.19 & 0.37 & 0.17 & 0.05 & 0.14 & 0.14 \\
0.4 & 3.53 & 1.65 & 2.14 & 0.36 & 0.17 & 0.05 & 0.15 & 0.14 \\
0.6 & 3.56 & 1.68 & 2.12 & 0.36 & 0.18 & 0.06 & 0.15 & 0.14 \\
1.0 & 3.60 & 1.72 & 2.09 & 0.35 & 0.18 & 0.06 & 0.16 & 0.14 \\
2.0 & 3.65 & 1.76 & 2.07 & 0.35 & 0.18 & 0.06 & 0.16 & 0.14 \\
4.0 & 3.78 & 1.82 & 2.08 & 0.35 & 0.20 & 0.07 & 0.18 & 0.15 \\
6.0 & 3.92 & 1.89 & 2.07 & 0.35 & 0.21 & 0.07 & 0.19 & 0.16 \\
& & & & & & & & \\
Sample & $357-24, \mathrm{CC}(\rho=2.752 \mathrm{~g} / \mathrm{cc})^{\mathrm{b}}$ & & & & & \\
0.2 & 6.27 & 2.69 & 2.33 & 0.39 & 0.82 & 0.20 & 0.55 & 0.68 \\
0.4 & 6.29 & 2.69 & 2.34 & 0.39 & 0.82 & 0.20 & 0.55 & 0.69 \\
0.6 & 6.31 & 2.70 & 2.34 & 0.39 & 0.83 & 0.20 & 0.56 & 0.69 \\
1.0 & 6.34 & 2.71 & 2.34 & 0.39 & 0.84 & 0.20 & 0.56 & 0.70 \\
2.0 & 6.40 & 2.73 & 2.34 & 0.39 & 0.85 & 0.21 & 0.57 & 0.72 \\
4.0 & 6.48 & 2.75 & 2.36 & 0.39 & 0.88 & 0.21 & 0.58 & 0.74 \\
6.0 & 6.54 & 2.77 & 2.36 & 0.39 & 0.90 & 0.21 & 0.59 & 0.76 \\
\hline
\end{tabular}

${ }^{a}$ Dark greenish-gray sedimentary breccia; clasts primarily glassy basalt.

${ }^{\mathrm{b}}$ Medium dark gray, fine-grained dolostone.

A least-squares fit of these parameters on the 13 zero section data points (Figure 1) yields

$$
\rho=2.71-1.82 \phi
$$

with a correlation coefficient $(r)$ of 0.98 . The density of the pore medium estimated from the above expression is $0.89 \mathrm{~g} / \mathrm{cc}$, which suggests that some of the samples were slightly undersaturated or that some water was trapped in the samples after drying.

If grain density is uniform in marine sediments, porosity can be computed directly from water content measured in weight percent by

$$
\phi=w \rho_{g}\left[(1-w)-w \rho_{g}\right]^{-1}
$$




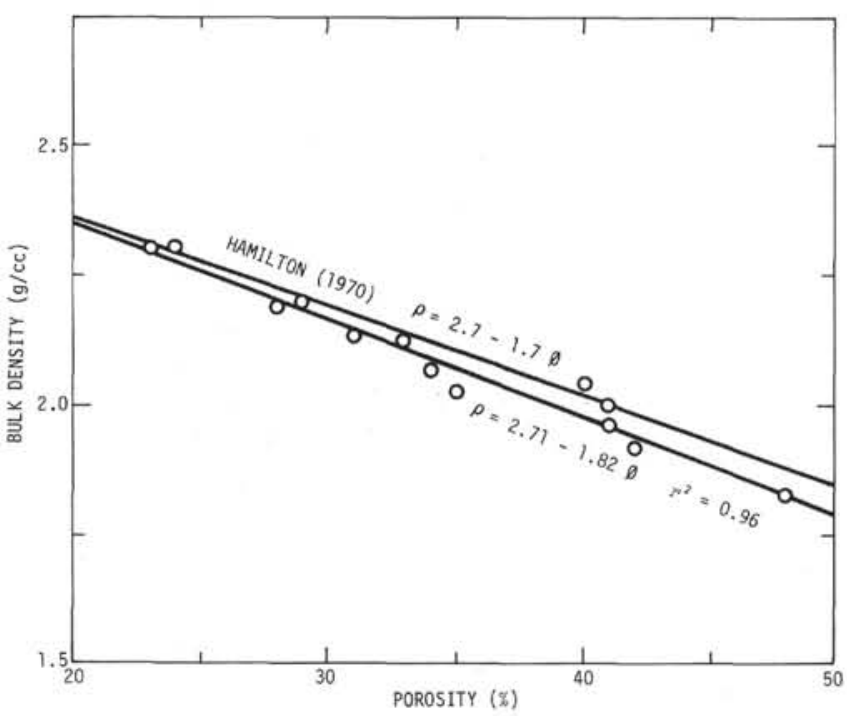

Figure 1. Porosity $(\phi)$ versus wet bulk density $\left(\rho_{\mathrm{b}}\right)$ of calcareous sediments.

where $w$ is weight percent water. Porosities computed using the above relationship and a grain density of 2.7 $\mathrm{g} / \mathrm{cc}$ show excellent agreement with the measured values.

Figure 2 shows a plot of porosity versus compressional wave velocity for the samples listed in Table 1. A least-squares fit of average velocity and porosity yields

$$
V_{p}=3.54-3.81 \phi(\mathrm{km} / \mathrm{sec})
$$

with a correlation coefficient of 0.92 . A similar relation obtained by Morton (1975) for calcareous sediments having porosities in excess of $70 \%$ predicts velocities considerably higher than those observed in this study. The discrepancy may reflect a nonlinear relationship between velocity and porosity as predicted by theory (Wood, 1941; Shumway, 1960a, b). However, velocities predicted by the emulsion equation (Wood, 1941) are significantly lower than the 0.1 kbar values of Figure 2 .

Velocity-density relations for the Leg 39 sediments are compared in Figure 3 with velocity-density data for DSDP basalts summarized by Christensen and Salisbury (1975). In terms of compressional velocity and density, the breccia is indistinguishable from highly altered, low density basalts. The velocity of the dolostone, however, is about $0.5 \mathrm{~km} / \mathrm{sec}$ higher than the velocities of basalts having similar densities. Though the limestones and chalks show the expected increase in velocity with increasing density, the velocities of weathered basalts of corresponding density are approximately $1.0 \mathrm{~km} / \mathrm{sec}$ higher.

\section{ANISOTROPY}

Shipboard velocity measurements, summarized in Table 3, suggest that many of the sediments are anisotropic. $V_{h}$ and $V_{v}$ refer to the measured velocities of compressional waves propagating perpendicular and parallel to the drill core axis, respectively. Percent anisotropy $(A)$ is related to velocity by

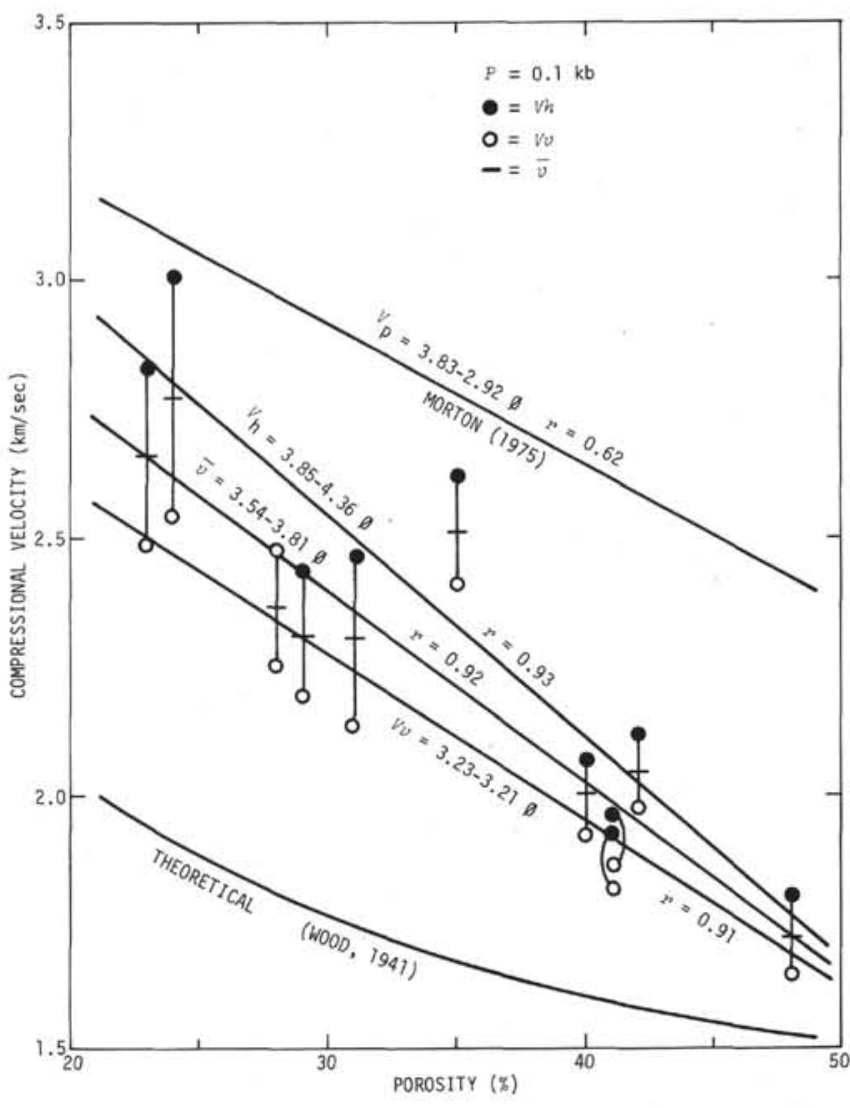

Figure 2. Compressional velocity at 0.1 kbar versus porosity of calcareous sediments.

$$
A=2\left(V_{h}-V_{v}\right)\left(V_{h}+V_{v}\right)^{-1} .
$$

Thus, $A$ is negative when $V_{v}$ exceeds $V_{h}$. Velocities are highest in the horizontal direction in 34 of 38 cases listed in Table 3.

A plot of anisotropy as a function of depth (Figure 4) illustrates that seismic anisotropy increases with depth at Site 356. The observed correlation of anisotropy with depth of burial suggests that this phenomenon is related to compaction and/or the age of the sediment. In addition, the abrupt increase in anisotropy at 450 meters depth implies that there is some correlation of anisotropy with lithology.

Compressional wave velocities at in situ pressures (Table 1) support the shipboard measurments. For all samples in which anisotropy was measured, the horizontal velocity exceeds the vertical velocity, and anisotropy tends to increase with increasing density (Figure 3) and decreasing porosity (Figure 2). Anisotropies computed from velocities measured at 0.1 kbar are included in Figure 4. Though anisotropy is enhanced by the confining pressure, the pattern is similar to that of the shipboard data. It is also significant that velocity anisotropy is observed in sediments recovered from Sites 354 and 357 as well as Site 356 , with values ranging from $5.2 \%$ to $16.2 \%$.

Though the Leg 39 sediments are highly calcareous rather than silty, the results of this study tend to substantiate Hamilton's (1970) conclusion that velocities in the horizontal plane increase significantly 


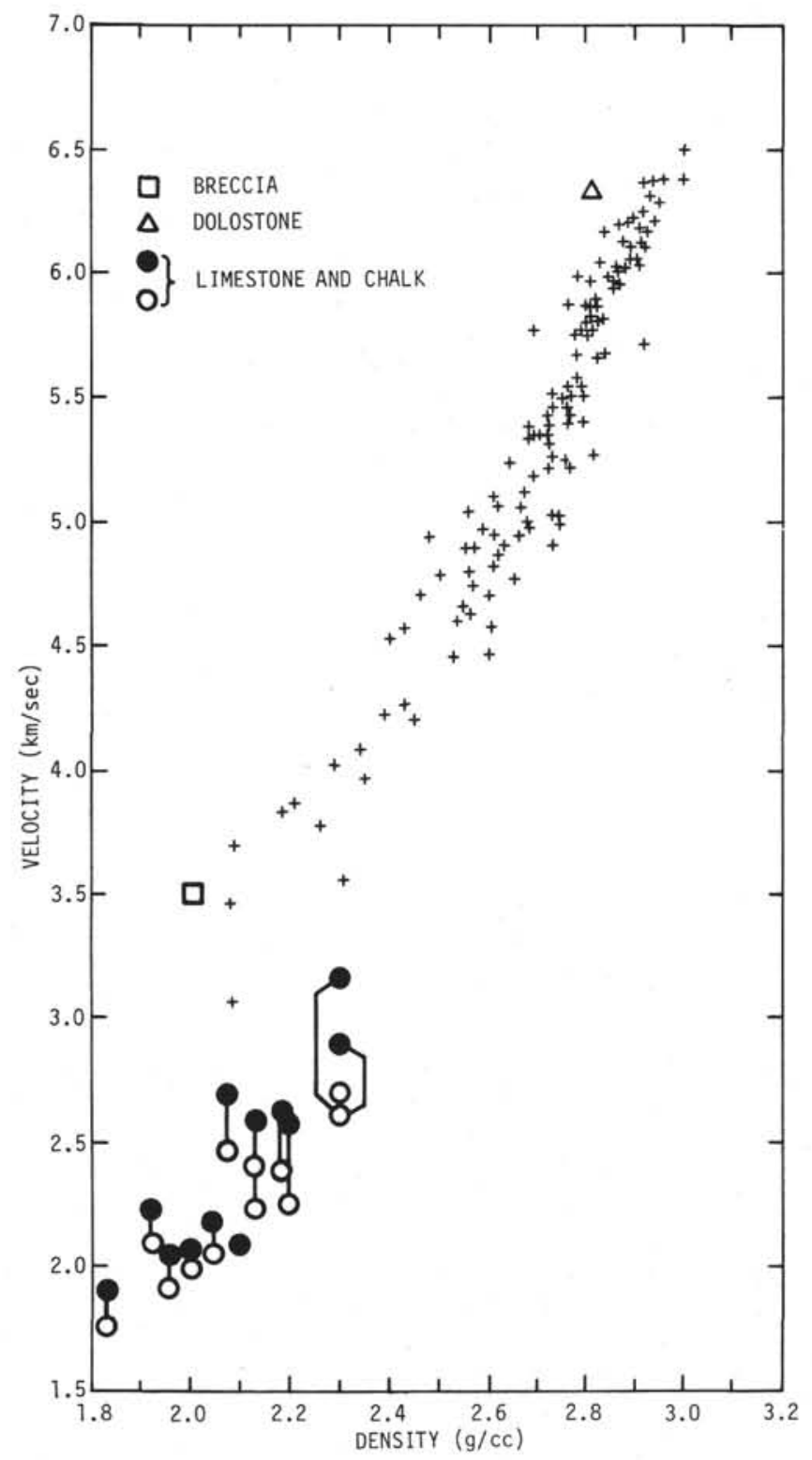

Figure 3. Compressional velocity measured at $0.5 \mathrm{kbar}$ versusdensity. Solid circles $(\mathrm{H})$ and open circles $(\mathrm{V})$ refer to horizontal and vertical velocities of calcareous sediments. Sample pairs are connected by solid lines. Pluses refer to DSDP basalt data (Christensen and Salisbury, 1975).

at depths of 400 to 600 meters. However, because of the calcareous nature of these samples, it is not clear that anisotropy can be attributed to mineral reorientation under compaction, as in the case of silts (Laughton, 1957; Ward et al., 1959, 1965). Cementation and recrystallization may well be more important in producing the observed anisotropy. The increase in anisotropy with decreasing porosity suggests that the horizontal velocities are more sensitive to porosity and velocities measured in the vertical direction, and independent regressions of $V_{h}$ and $V_{v}$ on $\phi$ support this conclusion. The least-squares equations are

$$
V_{h}=3.85-4.36 \phi(\mathrm{km} / \mathrm{sec}), r=0.93 \text { and }
$$

TABLE 3

Anisotropy vs. Depth

\begin{tabular}{|c|c|c|c|c|}
\hline $\begin{array}{c}\text { Sample } \\
\text { (Interval in } \mathrm{cm} \text { ) }\end{array}$ & $\begin{array}{l}\text { Depth } \\
\text { (m) }\end{array}$ & $\begin{array}{c}V_{h} \\
(\mathrm{~km} / \mathrm{sec})\end{array}$ & $\begin{array}{c}V_{v} \\
(\mathrm{~km} / \mathrm{sec})\end{array}$ & $\begin{array}{l}A \\
(\%)\end{array}$ \\
\hline $9-2,48$ & 191.98 & 1.654 & 1.620 & 2.077 \\
\hline $10-2,148$ & 221.48 & 1.899 & 1.997 & -5.031 \\
\hline $10-3,2$ & 221.52 & 2.123 & 2.136 & -0.610 \\
\hline $10-4,15$ & 223.15 & 2.396 & 2.466 & -2.879 \\
\hline $11-1,52$ & 238.02 & 1.875 & 1.846 & 1.559 \\
\hline $13-2,38$ & 258.38 & 1.846 & 1.791 & 3.024 \\
\hline $24-1,149$ & 362.49 & 1.821 & 1.783 & 2.109 \\
\hline $24-3,149$ & 365.49 & 1.787 & 1.835 & 2.316 \\
\hline $24-5,149$ & 368.49 & 1.910 & 1.883 & 1.424 \\
\hline $25-2,103$ & 373.03 & 1.822 & 1.703 & 6.752 \\
\hline $26-6,36$ & 387.86 & 1.830 & 1.785 & 2.490 \\
\hline $28-1,133$ & 400.33 & 1.896 & 1.813 & 4.476 \\
\hline $28-3,87$ & 402.87 & 1.918 & 1.866 & 2.748 \\
\hline $31-6,15$ & 444.65 & 1.886 & 1.870 & 0.852 \\
\hline $32-1,117$ & 457.17 & 2.032 & 1.968 & 3.200 \\
\hline $33-2,132$ & 487.32 & 2.181 & 2.036 & 6.877 \\
\hline $34-6,134$ & 521.84 & 2.244 & 2.070 & 8.067 \\
\hline $35-1,140$ & 542.90 & 2.280 & 2.104 & 8.029 \\
\hline $35-3,29$ & 544.79 & 2.137 & 2.007 & 6.274 \\
\hline $35-6,73$ & 549.73 & 2.202 & 2.035 & 7.883 \\
\hline $36-1,18$ & 570.18 & 2.199 & 2.073 & 5.899 \\
\hline $37-2,146$ & 601.46 & 2.345 & 2.242 & 4.491 \\
\hline $37-3,149$ & 602.99 & 2.279 & 2.345 & -2.855 \\
\hline $37-5,58$ & 605.88 & 2.450 & 2.286 & 6.926 \\
\hline $38-1,149$ & 647.49 & 2.456 & 2.289 & 7.039 \\
\hline $39-2,149$ & 677.49 & 2.525 & 2.372 & 6.249 \\
\hline $39-4,142$ & 680.42 & 2.447 & 2.288 & 6.716 \\
\hline $40-1,65$ & 694.15 & 2.529 & 2.463 & 2.644 \\
\hline $40-3,127$ & 697.77 & 2.388 & 2.292 & 4.103 \\
\hline $40-6,84$ & 701.84 & 2.763 & 2.715 & 1.752 \\
\hline $41-2,48$ & 704.98 & 2.372 & 2.221 & 6.575 \\
\hline $41-4,119$ & 708.69 & 2.966 & 2.845 & 4.165 \\
\hline $41-5,145$ & 710.25 & 3.086 & 2.839 & 8.338 \\
\hline $42-1,105$ & 713.55 & 3.143 & 2.861 & 9.394 \\
\hline $43-1,148$ & 723.48 & 3.189 & 2.865 & 10.704 \\
\hline $43-3,2$ & 725.02 & 2.905 & 2.799 & 3.717 \\
\hline $43 \cdot 5,148$ & 729.48 & 3.846 & 3.524 & 8.738 \\
\hline $44-3,108$ & 735.58 & 2.949 & 2.658 & 10.380 \\
\hline
\end{tabular}

$$
V_{v}=3.23-3.21 \phi(\mathrm{km} / \mathrm{sec}), r=0.91 \text {. }
$$

The rapid decrease in $V_{h}$ with increasing porosity implies that pore spaces affecting horizontal velocities are closed more rapidly by mineral reorientation, cementation, or recrystallization that are pore spaces affecting velocities in the vertical direction.

\section{ACKNOWLEDGMENTS}

We wish to thank V. Kiefer, J. Hull, J. Willemin, and K. Hubert for technical assistance. Financial support was provided by the Office of Naval Research Contract N-001467-A-0103-0014.

\section{REFERENCES}

Birch, F., 1960. The velocity of compressional waves in rocks to 10 kilobars, 1: J. Geophys. Res., v. 65, p. 1083. 1961. The velocities of compressional waves in rocks to 10 kilobars, 2: J. Geophys. Res., v. 66, p. 2199.

Christensen, N.I., 1965. Compressional wave velocities in metamorphic rocks at pressures to 10 kbar: J. Geophys. Res., v. 70, p. 6147. 


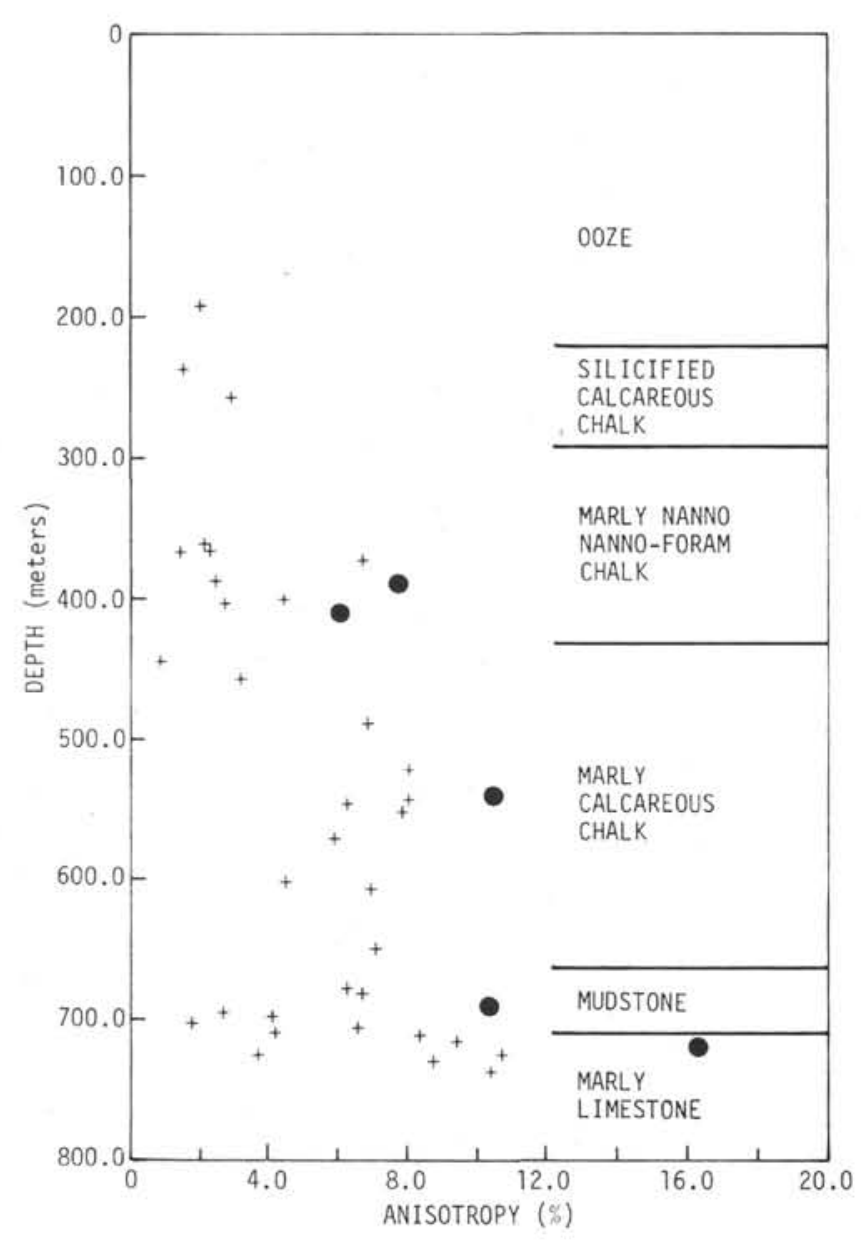

Figure 4. Anisotropy versus depth for sediments from Site 356. Pluses represent shipboard data (Table 3). Solid circles refer to shore-lab data, $\mathrm{P}=0.1 \mathrm{kbar}$.

Christensen, N.I. and Salisbury, M.H., 1975. Structure and constitution of the lower oceanic crust: Rev. Geophys. Space Phys., v. 13, p. 57.
Christensen, N.I. and Shaw, G.H., 1970. Elasticity of mafic rocks from the Mid-Atlantic Ridge: Geophys. J. Roy. Astron. Soc., v. 20, p. 271.

Hamilton, E.L., 1970. Sound velocity and related properties of marine sediments, North Pacific: J. Geophys. Res., 75, 4423-4446.

Hamilton, E.L., 1971. Elastic properties of marine sediments: J. Geophys. Res., v. 76, p. 579.

Laughton, A.S., 1957. Sound propagation in compacted ocean sediments: Geophysics, v. 22, p. 233.

Morton, R.W., 1975. Sound velocity in carbonate sediments from the Whiting Basin, Puerto Rico: Marine Geol., v. 19, p. 1.

Morton, R.W., 1975. Sound velocity in carbonate sediments from the Whiting Basin, Puerto Rico: Marine Geol., v. 19, p. 1.

Nur, A. and Simmons, G., 1969. The effect of saturation on velocity in low porosity rocks: Earth Planet. Sci. Lett., v. 7, p. 183.

Shumway, G., 1960a. Sound speed and absorption studies of marine sediments by a resonance method, 1: Geophysics, v. 25 , p. 451 .

Shumway, G., 1960b. Sound speed and absorption studies of marine sediments by a resonance method, 2: Geophysics, v. 25, p. 659 .

Ward, W.H., Marsland, A., and Samuels, S.G., 1965. Properties of the London Clay at the Ashford Common Shaft: In situ and undrained strength tests: Geotechnique, v. 15 , p. 321 .

Ward, W.H., Samuels, S.G. and Butler, M.E., 1959. Further studies of the properties of London clay: Geotechnique, v. 9, p. 33 .

Wood, A.B, 1941. A textbook of sound: London, (G. Bell), $298 \mathrm{pp}$.

Wyllie, M.R.J., Gregory, A.R., and Gardner, G.H.F., 1958. An experimental investigation of factors affecting elastic wave velocities in porous media: Geophysics, v. 23, p. 459 . 